[Original Article]

\title{
A study on the trends of mortality patterns in Japan using PMI
}

\section{Katsumi KANO* and Seiya YAMAGUCHI*}

\section{Introduction}

The structure of the population of Japan has been rapidly changing and the proportion of old people against the total population has been increasing. Such a change in the population has affected both the pattern of diseases and the mortality patterns.

Although the mortality patterns are usually analyzed by sex, age, or age group, we analyzed them using Proportional Mortality Indicator or PMI which was introduced by Drs. Swaroop, S. and Uemura, K. in WHO (1957). This indicator is a very simple one, but is useful as a health parameter, because we can see the health status of the observed population without knowing its structure.

The purpose of this study is to observe the trends of mortality patterns of the main causes of deaths besides all causes of deaths in Japan using PMI, and to consider the background circumstances or causes of its change.

\section{Materials and Methods}

The data used in this study was obtained from the vital statistics in Japan (1920-1978) which includes the number of deaths by sex and age for each cause of death.

PMI is usually calculated as the proportion of the number of deaths of over 50 year-olds against the total number of deaths. Thus, the age adopted for the ordinary PMI calculation is 50. In this study, however, we used 50,60,
70, and 80 as basic ages and the PMI are shown as $\mathrm{PMI}_{\mathrm{n}}$ where $\mathrm{n}$ indicates the basic ages.

\section{Results}

Fig. 1 shows the annual change of $\mathrm{PMI}_{50}$, $\mathrm{PMI}_{60}, \mathrm{PMI}_{70}$, and $\mathrm{PMI}_{80}$ using all causes of deaths from 1920 to 1978. Solid lines represent males and broken lines females.

Before World War II, there was little change in each PMI for both males and females. For example, the top line in this graph $\mathrm{PMI}_{50}$ ranges from 30 to 40 percent from 1920 to 1940 . Since the war, there has been a constant rise in all PMI both for males and females. In 1978, $\mathrm{PMI}_{50}$ reached $81.86 \%$ and $88.15 \%$ for males and females respectively. It should be noted that PMI is higher for females than for males at any basic age except for $\mathrm{PMI}_{5}$ o up till 1936.

Table 1 shows the regression lines for the PMI at each basic age for both sexes. The regression lines which correspond to observed values were calculated over various periods of time on the basis that the correlation coefficient between the values of the PMI and year is over $0.9(\mathrm{p}<0.001)$.

Before the war from 1920 to 1940 , the slopes of the regression lines were not as steep as compared with those after the war for each PMI. Since the war, the slopes of the regression lines have been increasing. Although the points of sudden change in the slope are

*. 筑波大学社会医学系

* Insitute of Community Medicine, The University of Tsukuba 
Fig. 1 Annual Change of PMI (All Causes of Deaths)

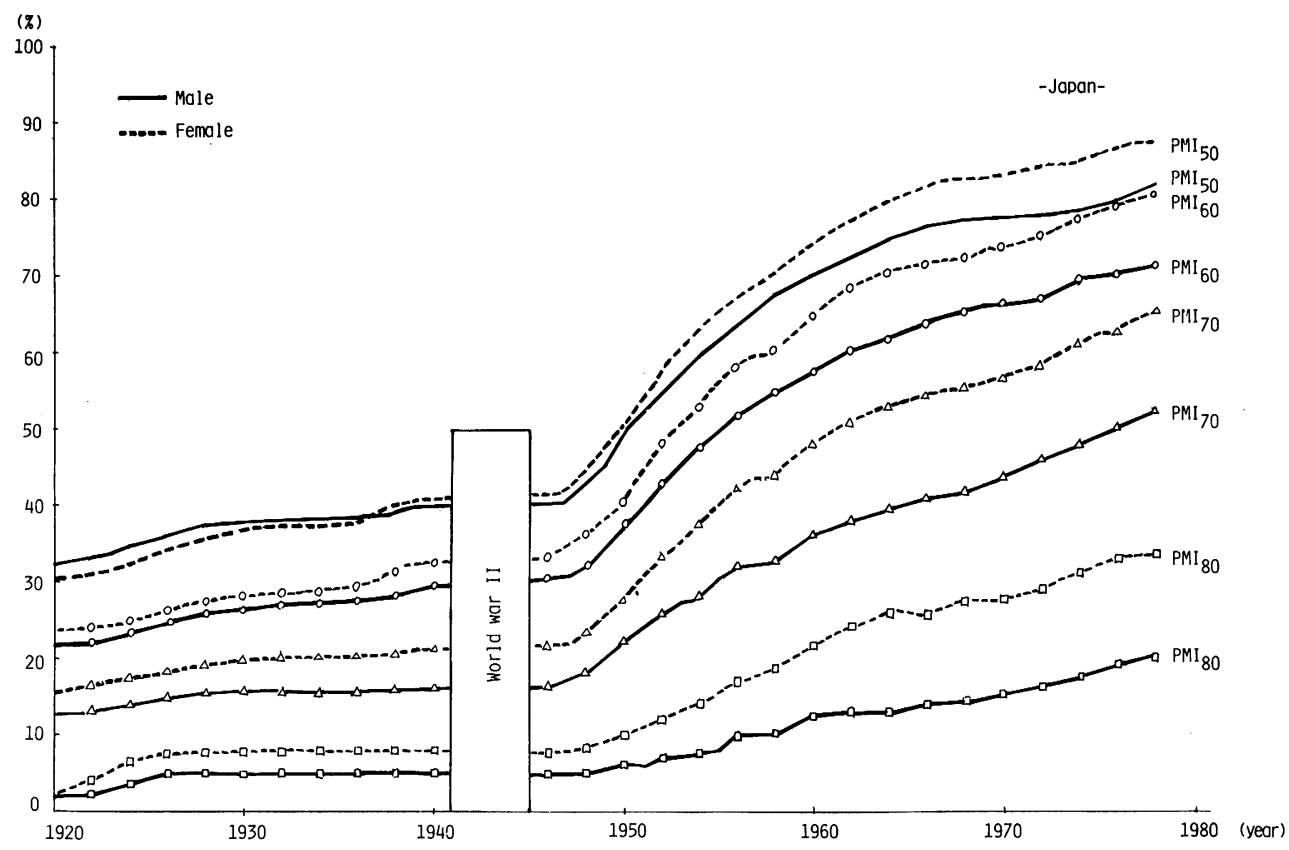

Table $1 \mathrm{PMI}_{\mathrm{n}}$ and Regression lines

\begin{tabular}{l|llllllll}
\hline \multirow{2}{*}{ PMI } & \multicolumn{2}{|c}{ PMI $_{50}$} & \multicolumn{2}{c}{ PMI $_{60}$} & \multicolumn{2}{c}{ PMI $_{70}$} & \multicolumn{2}{c}{ PMI $_{80}$} \\
\hline Sex & Male & Female & Male & Female & Male & Female & Male & Female \\
\hline \multirow{2}{*}{ Year } & $1920-$ & $1920-$ & $1920-$ & $1920-$ & $1920-$ & $1920-$ & $1920-$ & $1920-$ \\
Regres- & 1940 & 1940 & 1940 & 1940 & 1940 & 1940 & 1940 & 1940 \\
sion & -758.31 & -990.68 & -503.78 & -569.55 & -237.44 & -569.55 & -148.49 & -344.23 \\
line & $+0.41 \mathrm{x}$ & $+0.53 \mathrm{x}$ & $+0.28 \mathrm{x}$ & $+0.30 \mathrm{x}$ & $+0.13 \mathrm{x}$ & $+0.30 \mathrm{x}$ & $+0.08 \mathrm{x}$ & $+0.18 \mathrm{x}$ \\
\hline \multirow{2}{*}{ Year } & $1947-$ & $1947-$ & $1947-$ & $1947-$ & $1947-$ & $1947-$ & $1947-$ & $1947-$ \\
Regres- & 1966 & 1962 & 1959 & 1960 & 1959 & 1960 & 1962 & 1962 \\
sion & $\mathrm{y}=$ & $\mathrm{y}=$ & $\mathrm{y}=$ & $\mathrm{y}=$ & $\mathrm{y}=$ & $\mathrm{y}=$ & $\mathrm{y}=$ & $\mathrm{y}=$ \\
line & +3510.59 & -4405.38 & -4047.51 & -4511.54 & -2929.44 & -3983.09 & -1199.25 & -2247.34 \\
& $+1.83 \mathrm{x}$ & $+2.29 \mathrm{x}$ & $+2.10 \mathrm{x}$ & $+2.33 \mathrm{x}$ & $+1.51 \mathrm{x}$ & $+2.06 \mathrm{x}$ & $+0.61 \mathrm{x}$ & $+1.16 \mathrm{x}$ \\
\hline \multirow{2}{*}{ Year } & $1967-$ & $1964-$ & $1960-$ & $1961-$ & $1960-$ & $1961-$ & $1963-$ & $1963-$ \\
Regres- & 1978 & 1978 & 1978 & 1978 & 1978 & 1978 & 1978 & 1978 \\
sion & $\mathrm{y}=$ & $\mathrm{y}=$ & $\mathrm{y}=$ & $\mathrm{y}=$ & $\mathrm{y}=$ & $\mathrm{y}=$ & $\mathrm{y}=$ & $\mathrm{y}=$ \\
line & -756.26 & -1019.42 & -1298.46 & -1411.31 & -1617.07 & -1571.51 & -1298.46 & -1250.23 \\
& $+0.42 \mathrm{x}$ & $+0.56 \mathrm{x}$ & $+0.69 \mathrm{x}$ & $+0.75 \mathrm{x}$ & $+0.84 \mathrm{x}$ & $+0.83 \mathrm{x}$ & $+0.69 \mathrm{x}$ & $+0.65 \mathrm{x}$ \\
\hline
\end{tabular}


different for basic ages, they are all between 1947 and 1966. Before the war, the trend of $\mathrm{PMI}_{50}$ was higher for females than for males except for one short period.

The value of PMI is increasing year by year. From the slope of the regression line in this table we can see that the degree of the increase of PMI is different between males and females with that of females being greater than that of males. The increase of PMI for females between 1947 and 1960 is particularly marked.

Table 2 shows the change of $\mathrm{PMI}_{50}$ in the main causes of deaths in the years, 1935,
1950, 1955, 1965 and 1978.

The values of $\mathrm{PMI}_{50}$ in noninfectious chronic diseases such as cerebrovascular disease, malignant neoplasms, heart diseases and so on are high for every year selected and have been gradually increasing. The degree of increase, however, is not so great. On the other hand, infectious diseases such as pneumonia and bronchitis, tuberculosis, gastroenteritis and so forth have clearly increased markedly.

Fig. 2 and Fig. 3 show the PMI for typical causes of deaths in the form of graphs.

Fig. 2 depicts the annual trend of penu-

Table 2 Trends of $\mathrm{PMI}_{50}$ in Main Causes of Deaths

(Japan)

\begin{tabular}{|c|c|c|c|c|c|c|}
\hline \multirow{2}{*}{ Cause of death (ICD) } & \multirow{2}{*}{ Sex } & \multicolumn{5}{|c|}{ Year } \\
\hline & & 1935 & 1950 & 1955 & 1965 & 1978 \\
\hline \multirow{2}{*}{ B30 Cerebrovascular disease } & Male & 89.06 & 92.57 & 92.92 & 94.13 & 92.89 \\
\hline & Female & 89.51 & 92.26 & 93.31 & 95.87 & 96.68 \\
\hline \multirow{2}{*}{ B19 Malignant neoplasms } & Male & 82.72 & 72.31 & 82.89 & 85.83 & 86.95 \\
\hline & Female & 72.58 & 81.80 & 75.21 & 78.42 & 83.39 \\
\hline \multirow{2}{*}{ B26, B28, B29, Heart diseases } & Male & 67.45 & 74.66 & 81.05 & 88.70 & 89.61 \\
\hline & Female & 60.09 & 68.70 & 76.66 & 88.66 & 95.05 \\
\hline \multirow{2}{*}{ B32, B33a, B46d Pneumonia and Bronchitis } & Male & 23.99 & 34.26 & 43.14 & 71.33 & 91.64 \\
\hline & Female & 18.28 & 31.56 & 41.32 & 72.01 & 92.14 \\
\hline \multirow{2}{*}{ BE47, BE48 All accidents } & Male & 19.06 & 18.56 & 22.36 & 30.49 & 39.93 \\
\hline & Female & 24.19 & 20.87 & 26.97 & 47.07 & 60.07 \\
\hline \multirow{2}{*}{ B45a Senility } & Male & 100.00 & 100.00 & 100.00 & 100.00 & 100.00 \\
\hline & Female & 100.00 & 100.00 & 100.00 & 100.00 & 100.00 \\
\hline \multirow{2}{*}{ B27 Hypertensive disease } & Male & 96.03 & 96.03 & 94.18 & 95.16 & 96.46 \\
\hline & Female & 96.51 & 96.51 & 94.94 & 96.54 & 98.63 \\
\hline \multirow{2}{*}{ BE49 Suicide } & Male & 37.11 & 50.66 & 28.22 & 42.64 & 36.34 \\
\hline & Female & 35.34 & 45.63 & 30.59 & 46.14 & 52.84 \\
\hline \multirow{2}{*}{ B37 Cirrhosis of liver } & Male & 73.59 & 74.96 & 79.39 & 77.66 & 69.10 \\
\hline & Female & 72.23 & 77.22 & 80.14 & 84.54 & 88.59 \\
\hline \multirow{2}{*}{ B21 Diabetes mellitus } & Male & 70.65 & 74.73 & 79.51 & 88.35 & 87.46 \\
\hline & Female & 69.09 & 71.23 & 75.75 & 87.10 & 93.88 \\
\hline \multirow{2}{*}{ B5, B6 Tuberculosis, all forms } & Male & 12.14 & 21.30 & 41.68 & 70.95 & 87.96 \\
\hline & Female & 7.46 & 13.72 & 28.25 & 55.90 & 83.69 \\
\hline \multirow{2}{*}{ B4, B46e Gastroenteritis } & Male & 15.09 & 29.07 & 47.95 & 63.79 & 88.75 \\
\hline & Female & 21.13 & 36.71 & 58.03 & 82.90 & 95.25 \\
\hline \multirow{2}{*}{ B38 Nephritis and nephrosis } & Male & 64.68 & 65.10 & 67.04 & 60.88 & 79.96 \\
\hline & Female & 62.17 & 65.12 & 68.29 & 67.72 & 84.88 \\
\hline \multirow{2}{*}{ B34 Peptic ulcer } & Male & 65.41 & 71.51 & 79.01 & 83.95 & 86.93 \\
\hline & Female & 64.86 & 73.51 & 80.63 & 91.07 & 95.90 \\
\hline
\end{tabular}


monia and bronchitis for each PMI. Each PMI has increased rapidly after the war. And $\mathrm{PMI}_{50}$ reached more than 90 percent in 1978 for both sexes. $\mathrm{PMI}_{80}$ reached more than 30 percent in the same year.

Fig. 3 shows PMI for cerebrovascular disease which is the number one cause of deaths in Japan.

\section{Discussion}

The decrease of the mortality rate by infectious diseases and the increase of the mortality rate by noninfectious diseases is considered to be one of the main causes of the rapid increase in the PMI. Before World War II $\mathrm{PMI}_{50}$ was under 40 percent. This means that before the war there were few people who lived for more than 50 years. An old Japanese saying says that "Jinsei Wazuka Gojūnen" which means "Human life lasts only 50 years". The curve of $\mathrm{PMI}_{50}$ before the war gives some truth to this saying. On the other hand, $\mathrm{PMI}_{\mathbf{8 0}}$ is less than 10 percent before the war which means there were very few people, both male and female, who lived for more than 80 years.

From the regression analysis, it is not expected that $\mathrm{PMI}_{50}$ will increase as much in the future as in the past. On the other hand, it is expected that $\mathrm{PMI}_{70}$ and $\mathrm{PMI}_{80}$ will keep on increasing for a while longer. From the trends of PMI for pneumonia and bronchitis we can see that death by pneumonia and bronchitis was prevalent among children or youths in the past, but at present it is prevalent among old people. People who contact penumonia and bronchitis can recover easily with the aid of antibiotics and so forth, if they are in a younger age group. If they are older, it is difficult to recover even if they

Fig. 2 B32, B33a, B46d Pneumonia and Bronchitis

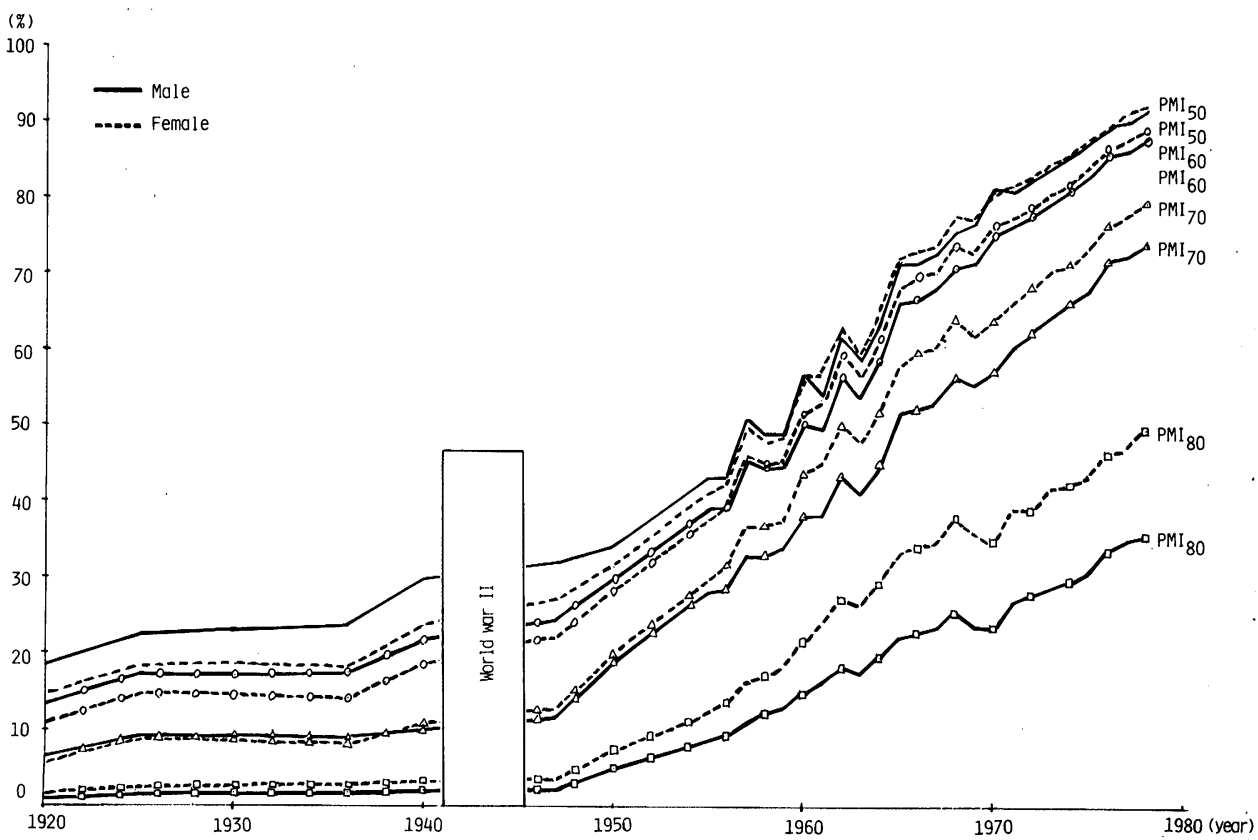


receive good medication because of a lack of resistance to the disease.

There are sex differences for each PMI. PMI for females are higher than for males. Data from a national survey undertaken in 1975 indicates that in almost all age groups the prevalence rates for females are higher than for males. Death is generally considered to be the outcome of the most advanced state of an illness. One possible explanation is that females seek medical care more freely and frequently than males and have diseases cured at an earlier stage. Of course the biological differences of the sexes are also to be considered.

$\mathrm{PMI}_{50}$ for cerebrovascular disease has remained fairly constant since 1920 . The values of $\mathrm{PMI}_{50}$ are about 90 percent. The values of $\mathrm{PMI}_{60}, \mathrm{PMI}_{70}$ and $\mathrm{PMI}_{80}$ have been increasing since the war. This shows that death by cerebrovascular disease has been prevalent among over 50 year-olds both in the past and the present, but death by this disease is becoming more common among over 70 or 80 year-olds, one of the reasons being that since the war prevention of cerebrovascular disease has been carried out in Japan effectively in a younger age group.

\section{Summary}

The mortality patterns in Japan have been changing rapidly since World War II. The mortality rate by infectious diseases has been declining markedly. On the other hand, the mortality rate by noninfectious diseases has been rising.

PMI is the health indicator usually used to show the proportion of deaths of over 50 year-olds against the total number of deaths. This indicator is a simple one, but is useful as a health parameter, because we can see the health status of the observed population

Fig. 3 B30 Cerebrovascular disease

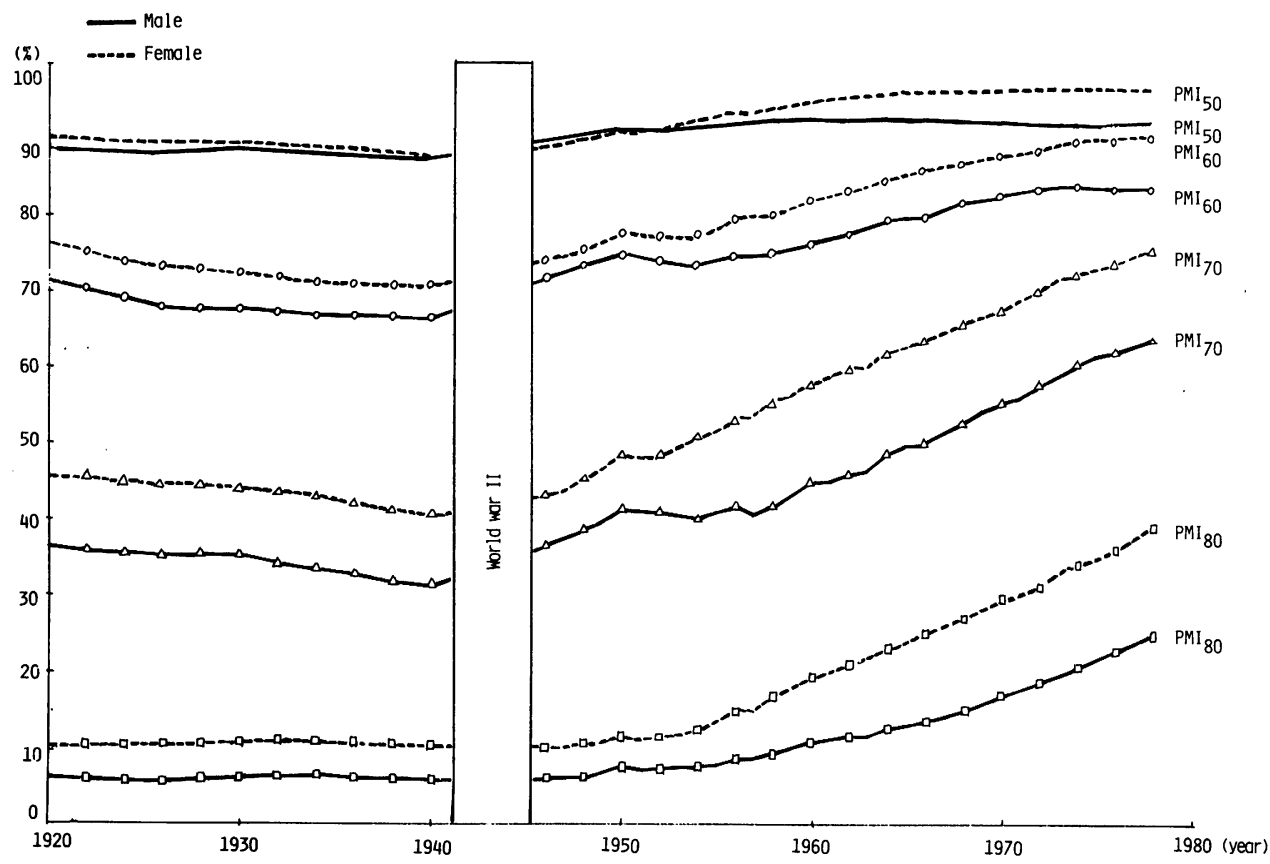


without knowing its structure.

The authors applyed this indicator to the analysis of the secular trends of death by major causes besides all causes in Japan from 1920 to 1978 . However, the basic ages employed in this calculation were $50,60,70$ and 80 whereas PMI calculation normally uses only 50 .

The results obtained were shown in the form of different regression lines. The trends were obviously different before and after World War II with regard to cause, sex and age. Although the values of PMI for pnemonia and bronchitis, for example, were under 30 percent for both males and females before the war, they increased rapidly and reached more than 90 percent. This phenomena explaines that death by these diseases was more prevalent among younger people in the past, but at present it is prevalent among old people.
References

Health and Welfare Statistics Department (19201978): Vital Statistics Japan, 1920-1978, Ministry of Health and Welfare, Tokyo, Japan

Health and Welfare Statistics Department(1980): KOKUMIN-EISEI NO DOUKO (Trend of Health Status in Japan) 27(9), 127-133

Health and Welfare Statistics Department(1980): KOKUMIN KENKO CHOSA (National Survey of Health, Japan), 10-11, Ministry of Health and Welfare, Tokyo, Japan

Swaroop. S. \& Uemura, K. (1957): Propor tional Mortality of 50 Years and Above, Bull. WHO, 17: $349-481$

WHO (1957): Measurement of levels of HealthReport of Study Group, WHO Techn. Rep. Ser. 137, 11- 12

〔和文抄録〕

PMI を用いた我が国の死亡構造の推移に関する研究

\section{加納克己 山口誠哉}

PMI (Proportional Mortality Indicator)は全死 亡数の中に占める50才以上の死亡割合を示す健康 指標の一つである。この指標の算出は簡単である が人口構成の知識なくして観察集団の健康水準を 把握することができるとともに死亡構造について も明らかにすることができるために粗死亡率より も有用であるといえる。

著者はPMI を用いて1920年から1978年における 我が国の全死亡のみならず，脳血管疾患，悪性新 生物，心疾患など14の主要死因の長期傾向につい て，従来用いられた50才の基準年齢の代わりに50 才だけでなく60才，70才，80才を用いて分折した。
その結果，全死因に関しては第 2 次世界大戦の前 と後では明らかに傾向の違いがみられ，戦後の著 しい上舁が認められた。とくに肺炎及び気管支炎 は戦前は男女とよに30\%を割っていたのに戦後は 急激に上昇し，男女ともに1978年には $\mathrm{PMI}_{50}$ で90 \%以上となり，これらの疾患による死亡が若年層 から高年齢層に移動したことを示している。また 脳血管疾患における PMI は戦前も $90 \%$ 近くで極め て高かったが $\mathrm{PMI}_{60} ， 70 ， 80$ においても高くなり つつあり，この疾患による死亡がさらに高年秢に 移動していることを示咍している。 